\title{
An Interdiscursive Analysis of Post-The Innocence of Muslims Political Discourse at UN Forum
}

\author{
Shazia Ayyaz ${ }^{1}$ \\ ${ }^{1}$ Department of English (UGS), National University of Modern Languages, Islamabad, Pakistan \\ Correspondence: Shazia Ayyaz, Department of English (UGS), National University of Modern Languages, \\ Islamabad, Pakistan. E-mail: shazia.ayaz25@gmail.com or saayyaz@numl.edu.pk
}

Received: September 19, 2017 Accepted: October 5, 2017 Online Published: October 25, 2017

doi:10.5539/ijel.v7n6p275 URL: http://doi.org/10.5539/ijel.v7n6p275

\begin{abstract}
This research focusses the interdiscursive analysis of political discourse to expose the hegemonic relations in the world politics. It is backgrounded in the issue of blasphemy that emerged after the release of the movie trailer The Innocence of Muslims. The researcher restricted the context of the study to the UN General Assembly meeting September 2012 where the issue was discussed in the presence of world political leaders. The data of the study contains the speech of the US president Barak Obama and is analyzed by using Fairclough's (1992) concept of interdiscursivity and hegemony. The analysis is focused on the discourse of the dominant political actor to find out the power relations and hegemony as exposed through the interdiscursive references present in his discourse. The study concludes that the dominant political leader uses different discursive strategies to construct and sustain power relations and hegemony. Interdiscursivity helps him to construct powerful self-image and to marginalise the subordinate group by highlighting its negative aspects and suppressing its ideologies.
\end{abstract}

Keywords: dominant political discourse, The Innocence of Muslims, interdiscursivity, hegemony, issue of blasphemy.

\section{Introduction}

\subsection{The Innocence of Muslims}

The release of the movie trailer The Innocence of Muslims on the YouTube is part of the series of events that happened in the Western world and hurt the religious emotions of the Muslims for the blasphemous content. The issue of blasphemy in this context starts from England with the publication of the novel Satanic Verses (1988) by Salman Rushdie, then Cartoon Crises in Europe 2005-2006 and the release of The Innocence of Muslims in July 2012. The Innocence of Muslims is a movie by Hollywood director Sam Bacile which contains offensive content about Islam and the last Prophet (S.A.W.W). The release of the video trailer on YouTube hurt the feelings of the Muslims around the world. They demanded a ban on the video and action against the maker and contributors. The reaction turned into violence when the US government did not act against the video and pronounced it as freedom of expression. The protests took many lives and caused the destruction of important buildings particularly the offices belonging to the US government. The situation was discussed in the UN General Assembly meeting in September 2012. The international political forum gave a chance to the political leaders of the Muslim world and the West to express their views on the divide of freedom of expression and blasphemy. That is why I have chosen this context and setting as a background for my study. The objective of my study is to find out power relations and hegemony in the context of the divide between the freedom of expression and blasphemy as exposed in the interdiscursive references present in the speech of President Barak Obama.

\subsection{Interdiscursivity}

The concept of interdiscursivity in this study is rooted in the theory of Critical Discourse Analysis that studies language in a social setup to expose ideologies of the social actors in the binary of power relations between the dominant and the subordinate social actors. Interdiscursivity in Critical Discourse Analysis is present as a part of intertextuality. The term "intertextuality" was introduced by Kristeva (1960), and Bakhtin (1981) developed it in his theory of dialogism. Bakhtin (1981) emphasised the dialogical nature of the texts because to produce every new text the voices already present in other text are transformed and used in the new text (Bakhtin, 1981, 1986). 
Kristeva (1980) used the term intertextuality while discussing different ways in which text and talk are used to produce new texts. Fairclough $(1992,2003,1999)$ introduced the concept of intertextuality in Critical Discourse Analysis. He defines it as "the property texts have of being full of snatches of other texts, which may be explicitly demarcated or merged in, and which the text may assimilate, contradict, ironically echo, and so forth" (Fairclough,1992, p. 84). Bakhtin (1981), Kristeva (1980) and Allen (2000) find texts as a meeting point of other texts and composite of utterances each of which is a form of dialogue (Sheyholislami, 2001).

Fairclough (1992) defines interdiscursivity as an instance of mixing of genres, discourses and styles in a text. Genres are ways of acting (interacting) i.e., speech, interview and lecture are different genres and they demand specific ways of acting and interacting with discourse users. Discourses are ways of representing like Medical discourse, political discourse etc. Styles are the ways of being a political leader, doctor, lawyer and so on (Fairclough, 2003). Styles are studied with reference to the tenor (with relation to the receiver), mode (form) and rhetorical mode (Fairclough, 1992).

\section{Methodology}

\subsection{Theory and Method}

\subsubsection{Interdiscursivity}

I have examined how interdiscursivity works in the power structure of the world political context by studying the data I have selected for my study. Theoretical base of my study is Fairclough's (1992) theory of intertextuality and hegemony in his book Discourse and Social Change. According to Fairclough (1992), the theory of intertextuality reveals the history of the texts by exposing their origins. He argues that theory of intertextuality alone is unable to expose the power relations in a social context which is the main core of the theory of critical discourse analysis. Therefore, he attaches it with the theory of hegemony to find out the interplay of power and hegemony through the intertexts present in a text. His concept approves that every text that is brought into another text has a role in constructing, sustaining and fracturing the power relations through discourse. He suggests the combination of hegemony theory with intertextuality. He thinks it can help to "list the possibilities and limitations for intertextual processes and the processes of constructing and restructuring orders of discourse as processes of hegemonic struggle in the sphere of discourse, which has effect upon as well as affected by hegemonic struggle in the wider sense" (Fairclough, 1992, p. 103). He followed this framework for analysing different texts. In his analysis, he focused on two dimensions of the intertextuality: manifest intertextuality and interdiscursivity. He explains manifest intertextuality in terms of discourse representations, presuppositions, negation, meta-discourse and irony and interdiscursivity that is mixing of genres, discourse, and styles in the text (Fairclough, 1992). The present study delimited the theory of intertextuality to interdiscursivity.

\subsubsection{Hegemony}

Hegemony is a part of the theoretical basis of the present study. The term hegemony came from Gramsci (1971) which influenced a great bulk of research in different disciplines. The concept of hegemony in the present study is based on the definition given by Fairclough (1992)

"Hegemony is a focus of constant struggle around points of greatest instability between classes and blocs, to construct or sustain or fracture alliances and relations of domination/subordination, which takes economic; political and ideological forms" (p. 92).

The point of instability for the present study is the divide between the concept of freedom of expression and blasphemy/religious freedom. The study has attempted to find out how political leaders through their discursive practice construct, sustain and fracture alliances and relation of domination and subordination. In the present study, the focus is purely on the political aspect.

\section{Data Analysis}

\subsection{Context}

President Barak Obama represents America and the West. He belongs to the dominant group in the global political context. In the background of the study, he belongs to the US and is in favour of freedom of expression rather than freedom of religion or blasphemy. At the time of the speech under discussion, his country was involved in different military actions against the Muslim countries i.e., Afghanistan, Pakistan, Iraq, Syria, Libya, Tunisia, Egypt. As a result, he was facing a lot of criticism from the world. It was the time when the Muslim world was protesting against the release of the video of the movie trailer The Innocence of Muslims and America was defending it as freedom of expression. The situation created negative feelings in the hearts of the Muslims. The situation worsened because of the intrusion of America in Arab countries, situation in Iraq, drone attacks in 
Pakistan and presence of the Western forces in Afghanistan, caused major disagreements between the Muslim world and the West/America.

The issue of blasphemy and freedom of expression came into prominence after the release of The Innocence of Muslims. The whole speech of Obama is based on the defence of his ideology of freedom of expression. However, he addressed this issue from different aspects. The speech can be divided into three parts, story of the ambassador Chris Stevens, Arab Spring and direct reference to the issue of the freedom of expression and blasphemy. His speech starts and ends with the story of American ambassador Chris Stevens who was killed in Benghazi, Libya. He discusses the positive effect of Arab Spring on some Middle Eastern and North African Muslim countries where people stood against their governments and toppled the existing leaders for a new government. However, both the matters are discussed with reference to the issue under study. Presently, I focus on his direct address to the issue of blasphemy to defend the idea of freedom of expression.

\subsection{Analysis}

While talking about the situation created after the release of The Innocence of Muslims, he starts with generalizing the issue by taking it out of the internal discourse of America. He shifts to the international discourse "in every country" and "that is what we saw" but his focus is not the video as he finds it a common and general issue (In every. ...threatening;) but he specifies the reaction and shifts from every country to every culture, gives more space to discuss and criticize the reaction against it (...those who.... for others.). He detaches himself from the negative actions of his group by further dividing his group e.g., from "America" to "United States government" so the discourses that criticise the video should not attack the government is the message but whom should they address is not specified by him. He mixes descriptive and Argumentative rhetorical modes. The former helps him keep himself out of the matter and the latter exposes his dominant stance and his powerful position. Static tenor also indicates his distance from the issue. After that, he brings the other group into his group to invalidate the protests on the release of the video (If we are...hold in common). He is de-emphasising the difference in the ideology of Muslims as one nation and generalising it to the common concept of nation. In this manner, he damages the identity of Muslims as one nation (Ummah) and splitting them on the regional and biographical grounds. Obama mixes the discourse of Muslims as a group and the internal discourse of America to marginalise the identity of Muslims a whole group. Rather they are depicted just as a small part of America itself. His argumentative and assertive style helps him to dominate the other discourse through his discourse that has more power than the other discourses present in the context due to the powerful position he enjoys.

He brings in the issue under discussion to the internal discourse of America from the international and internal discourse of the Muslim world. His attempt to indigenize the issue to get his full control on it makes him able to handle it in more comfortable manner and according to his ideologies and his interests in the world political order. It exposes the incompetence, inability and powerlessness of the Muslim world to deal with the issues related to their nation/religion. He discusses religion and races together as an endeavour to mollify the intensity of the issue under discussion (We not only respect.... what they believe.). Additionally, discussing this issue with reference to internal American discourse helps him to compare the religious ideologies of Muslims with the religious ideologies of other nations settled in America and mitigates the intensity of the matter. For this purpose, he mixes religious discourses (Islam and Christianity) and discusses that blasphemy against Christianity happens in America but never reacted in the manner Muslim reacted to the video. It is also an attempt to convince the Muslim world to accept the video as freedom of expression and their reaction against it is hyperbolic and larger-than-life. He is marginalising the emotional attachment of the Muslims with their faith and the Prophet (S.A.W.W). He also marginalises the basic ideology of the Muslims that does not take religion as a personal matter but as an ideology penetrated in their whole lives to justifies his action of not banning the video in a manipulative manner.

He includes himself in the discourse of blasphemy to politicise and to detach it from the religion, and so disprove the protests. It is an attempt to de-intensify the emotional attachment of the Muslims with the issue. He mixes religious ideologies with political ideologies by mixing two genres and discourses and establishing an analogy between himself and the basic ideals of Islam. It is a manipulative attempt to marginalise the religious ideology of the Muslim world. He glorifies his identity as the leader and "Commander in Chief of Military" and enhances the images and the dominant position of his group. The mix and shift of the religious discourse to the American political discourse reveal the highly oppressive attitude of Obama towards the Muslim world with special reference to the issue of blasphemy. He is not just rejecting the right of the Muslims to protest the blasphemous action against their religion but is also disproving the highly emotional attachment of the Muslims with their religion. He highlights the actions of some "Americans" (forces and ambassadors) to mollify the effect of the actions of other Americans (video makers) (Americans have fought.... disagree with). The positive actions of the 
Americans are not directed to the Muslims only, but it is to "all people" that means America is not concerned about the interests of the Muslims only but the whole world. However, Obama brought this argument in the context that gives an effect to the world that America is interested in working for the better future of Muslims. The manipulative and dominant nature of his discourse helps Obama to maintain the power position.

He shifts to the explanatory rhetorical style which exposes his concern about his position and the clarifications he makes to contest the opposition from the Muslim world for misunderstanding and marginalising their religious ideologies (We do not do so.......and mutual respect). His style loses force while giving explanations that exposes his struggle to sustain his position. Moreover, his explanations are not up to the mark concerning the issue of blasphemy but just endeavours to satisfy them and to justify his ideologies on the issue. He comes out from the political discourse to the social context and discusses the issue from a soft perspective that is focused on the reform of the tolerant society where people from different faiths and race can live together in peace and security. Obama here is striving to convince the Muslim world to rethink on their religious ideologies and attitudes with the help of bringing in the references from the other discourses and mixing the styles of argumentation and explanation. His discourse has the shadows of debate (genre) and discussion on the value of religion in the diverse modern society. He brings in different genres to establish that the religious beliefs in the modern world should not dominate the other matters like international relations, international cooperation and tolerance for diversity.

Obama uses the discourse from information technology to make his point convincing and to reveal the negative effects of protesting against the blasphemy (Now I know... is obsolete). The presence of modern informational technology in the context of the issue helps Obama to make his point valid, influence the ideologies of the other group and make them one with his ideology. He continues his struggle to prove the other group wrong in reacting against the blasphemy by bringing in the discourses of destruction and violence from the internal discourse of the Muslim countries to make his argument forceful and his ideological beliefs stronger than their religious ideologies (The question...destruction in Pakistan). The snatches of the texts from the discourse of blasphemy are brought in and contrasted with the references from the discourse of destruction and violence in the Muslim countries. The (blasphemous) speech is contrasted with mindless violence, words (blasphemous) with killing of innocents, video with attack to an embassy, slander with burning a restaurant, destroying a school and death and destruction in the Muslim world where the protests took place. His account of restricting himself to the internal discourse of the Muslim countries is intentional and it is done to make the point that if Muslims react to such actions, they will harm themselves and not the international community, America or the West. It shows dominance and oppression in the discourse of Obama which is enhanced by the exposure of his ideology that international safety, security and peace is higher than the religion. The safety of masses, schools, embassies (American) and restaurants is more important than the protection of the religious ideologies and beliefs. Eventually, Obama is successful in marginalising and suppressing the ideological beliefs and interests of the Muslim world and sustain the power position he struggled for in the previous part of his speech.

Obama mingles the discourse of modernity and technology with the religious discourse of blasphemy (In this modern world...towards democracy). He advocates the idea that the religion in the modern technological world should take a shift or change its shape from the previous one. He is de-emphasising the nature of the video by euphemising it as "hateful speech". His discourse is majorly focused on the reaction to the "hateful speech" and he hardly talks about the video or the people who made it. This is an endeavour to de-intensify the negative actions of his group by indulging most of the time in discussing the reaction of the other group and prove it more negative, serious and harmful for the safety of the whole world. He never stops diverting the issue from its actual shape and yet again he does it to blend the discourse from the Arab world, in his words "Arab Spring" and invites his audience to turn away from the basic issue and focus on the tension between the West and the Arab world. He goes further in lowering the activity of protests and terms them triggers for "chaos", and exposing "worst of us" and as a final diversion, he attaches the protests to the unrest in the Arab world of that time (2012).

Obama again brings the issue into the global discourse as he tries to establish the issue as a harm to the security and peace of the whole world. He invites the leaders from all around the world to condemn the protests. It is the discourse of suppression as it is attempting to merge the identities of the subordinate group in the dominant group and forcing the subordinate group to change their ideologies in the interests and favour of the dominant group. Furthermore, the dominant group is forcing the suppressed group not only to reject their ideologies but to speak out against them as they are not right and are "violence and extremism". Obama goes a step forward to make demands from the Muslim countries in asking them to react and take actions against the violence and extremism (the protests on the video) that is directed towards America and demands actions against those also who go against the ideals of America, the West or Israel. 
He politicises the issue of blasphemy by attaching it to political strategies and interests of the leaders from the Muslim countries with the help of snatches from the discourses of religion, internal as well as international politics and extremism (This brand of politics...democracy's promise). All these discourses are brought in to suppress and marginalise the discourse of blasphemy. He draws a clear line between his group and the other group by nominating it as "east, south and Muslims" and nominates his group as "west, north and Christians, Hindus, Jews" to confirm the geographical and religious differences between the two. Obama marginalises the ideologies of Muslims by grouping himself with major religions of the world leaving Islam. He groups the Muslims separate from the other religious grouping. This proves it different in negative sense and by grouping the other religions together to emphasise that the whole world shares his religious ideological beliefs while Muslims are odd and different. This comes under the discursive strategy of excluding certain discourses or groups to weaken their position in the power structure and to prove them and their ideologies wrong or threatening. Obama parallelises the discourse of blasphemy and the protests of the Muslims against America to mitigate the importance of the issue. He also politicises it to dismiss the possibility of religious emotions of the Muslims to be attached with it in real.

He uses the imperative style that is threatening, assertive and expresses the determination of Obama to be consistent with his ideologies (Understand....mutual respect.). The determination of being present in the internal discourse of different countries of the world. "Without retreat" reveals the suppression of the other group by Obama and his established dominance on them that allows him to intrude in their internal matters and decide their future himself. He separates the addressee group from his group, friends and allies. It shows the message from Obama to the other group to either be his friend or ally otherwise he will consider them enemies and will "bring justice to" them. There is a feeling of suppression and coercive power by Obama on the other group as he is not interested in winning the consent of them rather he warns them to be with him, or his friends or allies otherwise they will be crushed by him, his friends and allies. After establishing the dominance of the other group and suppressing them, he invites them to be one with him as partners. To give a positive and soft picture of his, he comes out from the political discourse and brings in discourses from science, technology, energy and development which are the needs and wants of the other group and are in the power of Obama. He further influences the other group by bringing in the economic growth and shift again to the political order to give a message to the other group that they can get whatever they want but only after being one with America and working for the interests of it.

The president takes a shift from international to the internal political discourse of the Muslim world to emphasise the harm they suffered for protesting against the issue of blasphemy. He de-emphasises the harms suffered by America with the help of passivisation and intensifies the events by individualising them (Turkish, Yemenis, Afghan), using active constructions and giving more details than the necessary information to establish that the protests are more dangerous and harmful for the Muslim world itself than America or the West. The intensification of the harms for the Muslim world exposes the ideology of Obama that is to prove the reaction of the Muslim world wrong and destructive for themselves i.e. "police officer murdered......days before his wedding", "10 Yemenis killed in car bomb", "Afghan children were mourned by their parents......killed by suicide bomber" and de-intensification of American "civilians were killed in Benghazi" (even identity of the civilians is not disclosed as Americans).

Obama challenges the very ideology behind the issue of blasphemy. "The impulse towards intolerance and violence...to chaos". He brings in the internal religious and social discourse of the Muslim world and reveals the divides present there based on sectarian differences and sociocultural variations. He reveals these internal divides to weaken the position of the Muslim world on the issue of blasphemy and dominates and suppresses their ideologies and conventions. He exposes the weaknesses of the other group to strengthen his position in the binary of power where the other group is powerless. He manipulates the division inside the Muslim world to establish his views and ideologies superior and righteous. The blend of the internal discourse of Muslims with the international political discourse by Obama is an indication that he has access to the religious, socio-cultural and political institutions of the Muslim world and this access is a step towards the control and dominance. Moreover, he also endeavours to expose the negative effects of the inner divide of the Muslim world and associates it on the divide between the blasphemy and freedom of expression to de-intensify the intensity and importance of the issue of blasphemy. This manipulative discursive strategy helps Obama to enhance the value to his ideologies and marginalise the ideologies behind the reaction against the video.

He continues with the metaphor of future and mixes discourses from different parts of the Muslim world. "The future must not belong...Holocaust that is denied." The future that is the favour of America and the West, is for those who work with and for the dominant group (at Tahrir Square where Muslims were together with Christians) 
not for those who are against them (who targeted Coptic Christians). Obama intentionally brings in the inter-religious discourse to debase the religious ideologies of the other group by attaching them to the negative actions that are "bully women" and "steal(ing) a country's resources" (politician). These allegations create a horrible picture of the opposite group and the parallel discourse that is detached from them by Obama further strengthen it e.g. women education, equality between male and female child, believe in the broader prosperity for all people. The ideologies detached from the opposite group are attached to his group. In other words, he wants Muslims to change their ideologies. Only then he will stand for them or the Muslims can get the support of the West only if they modernize themselves according to the needs of the modern world instead of following the traditional religious norms which hinder the progress and create problems for them to live with other communities of the world in a global village.

Obama refers to the discourse of blasphemy condemning the acts of slander against the Prophet (S.A.W.W.) of Islam which changes his position from the suppressor to the friend and ally of the Muslim world. He takes another shift to Christianity in order to mitigate the effect of his discourse and to reverse his position as a group other than the Muslims. The use of contrast as a discursive strategy makes him comfortable to shift his position without any problem. The contrast he brought in, is the blasphemy of Islam and blasphemy of Christianity. He blames the protesters against the video for not protesting the slander of the Christian beliefs. That exposes Obama's ambition for the other group, that is, they should be active equally for the interests of his group. In this way, he suppresses their right to speak against the violation of their religious rights. It is not only suppression but denial of the rights too by demanding to raise the voices to save the religious ideologies of his group. There he marginalises Muslim attachment to their religion to be stronger than that of the Christians.

Obama once again throws the light on the negative aspects of the internal religious discourse of the Muslims and highlights the marginalisation based on sects in the Muslim world as an attempt to debase their religious ideologies and mitigate the intensity of the issue of blasphemy. He attempts to establish that the ideologies shared by the Muslims who protested are not the ideologies of the whole Muslim group because the Muslims are inwardly separated into divisions based on the difference in the religious views (sects). This is an endeavour to weaken the stance of the Muslim world on the issue of blasphemy which they think cannot be discussed along with the debate of freedom of expression. After that, he gets back to the discourse of globalism and establishes the difference between his group and the Muslim world but aspires that all should be together to work for the interests of the whole world (America and the West). The direct discourse representation here is also opposing the religious ideology of the Muslims. Obama himself is attempting to convince Muslims to be one with his group to share his ideologies which belong to the dominant group and to shift their ideologies which made them subordinate and suppressed in the world political order.

\section{Conclusion}

President Obama utilises interdiscursive references to construct and sustain the power relations in the backdrop of the post The Innocence of Muslims situation which shook the world. Obama's views on the matter are different from the other group but he establishes his power and hegemony. He uses different strategies (i.e., marginalisation, individualisation, intensifying and de-intensifying emphasising and deemphasising, of certain ideologies and assumptions) to establish his views which help him to construct and sustain the power relations. Interdiscursivity plays an important role for him in construction and sustenance of the power relations. It helps him to shift from one to another discourse, genre and style to discuss different aspects of the issue. His shift of genres, discourse and styles expose his ideologies and establish his dominance in the world political order.

In the present study, the binary of power relations is set on the division of freedom of expression and religious freedom/blasphemy. The dominant group is in favour of the freedom of expression which suppresses the religious freedom of the subordinate group and marginalises their religious emotions and ideologies. It emphasises and intensifies the negative aspects of their concept of religious ideologies and declares them misfit in the modern world of technology. The dominant group de-emphasises the emotional attachment of the subordinate group with religion and debase them by making analogies between the freedom of expression and blasphemy. These analogies mitigate the significance of the Muslim ideologies. The dominant group divides the other group into the protesters against the video and the friends of America. The protesters are portrayed as destructive, cruel and violent and are dissociated from the Muslim world to win the consent of the Muslim world and make them realise that the protests on the release of the video were irrational. This is an example of exclusion and inclusion at the same time. The protesters are excluded from the Muslim world and the Muslim world is included in the dominant group just to win their consent. The suppression of the Muslim ideologies reveals the presence of the power relations between both the groups. The release of the video is a point of instability for power relations and hegemony that is overcome by the dominant with the help of discursive 
strategies and the power relations were recreated in the context of global political order.

The researcher believes the views of both the sides are valuable because the importance of freedom of expression cannot be denied for the progress of humanity. However, freedom of expression should not be hurting the emotions of any group either religious or other. There is a need of awareness for both the groups to understand one another and for this purpose, there should be an international documentation to handle the political manipulation of the ideologies of different groups which cause harm to both the sides. There should be a line between the freedom of expression and hurting the emotions.

\section{References}

Allen, G. (2000). Intertextuality. London: Routledge

Bakhtin, M. (1981). The dialogic imagination. Austin: University of Texas Press.

Bakhtin, M. (1986). Speech genres and other late essays. Austin: University of Texas Press.

Barak Obama Speech. (2012). Retrieved https://www.whitehouse.gov/the-press-office/2012/09/25/remarks-president-un-general-assembly

Chouliaraki, L., \& Fairclough, N. (1999). Discourse in late modernity: Rethinking critical discourse analysis. Edinburgh: Edinburgh University Press.

Fairclough, N. (1992) Discourse and social change. Cambridge: Polity.

Fairclough, N. (1992) Intertextuality in critical discourse analysis. Linguistics and Education, 4, 269-293. https://doi.org/10.1016/0898-5898(92)90004-G

Fairclough, N. (2003). Analyzing discourse: Textual analysis for social research. London: Routledge.

Gramsci A. (1971) Selections from the prison notebooks. In Q. Hoare \& G. N. Smith (1999). (Eds. and Trans.). London: ElecBook.

Kristeva, J. (1980). Desire in language: A semiotic approach to literature and art. In L. S. Roudiez (Ed.), T. Gora et al. (Trans.) (1980). New York: Columbia University Press.

Kristeva, J. (1986). The Kristeva reader. Oxford: Blackwell.

Sheyholislami, J. (2001). Critical discourse analysis. Unpublished manuscript, Carleton University, Ottawa, Ontario. Retrieved from http://http-server.carleton.ca/ jsheyhol/articles/what\%20is\%20CDA.pdf

\section{Copyrights}

Copyright for this article is retained by the author(s), with first publication rights granted to the journal.

This is an open-access article distributed under the terms and conditions of the Creative Commons Attribution license (http://creativecommons.org/licenses/by/4.0/). 